URL: http://dergipark.ulakbim.gov.tr/ijhbs/index

Volume: 2, Issue: 1, Year: 2016

DOI: http://dx.doi.org/10.19148/ijhbs.67063

\title{
An investigation of 4th Grade Students' Attitudes towards Music Class
}

\author{
Abdurrahim Can Eldemir \\ Çanakkale Onsekiz Mart University, Turkey \\ caneldemir@hotmail.com
}

\begin{abstract}
This study was carried out in order to analyze attitudes of primary school 4th grades students related to music class. This study using the general survey model was come out with 619 students who took course at five primary schools affiliated to Ministry of National Education in spring term of 2014-2015 academic years. In the study, data has been collected by using "personal information form and "Music Lesson Attitude Scale" developed by Nacakçı (2006). The data obtained has been analyzed by using statistical methods and presented in tables. According to study results, it can be said that attitudes of students related to music class are generally positive, primary school 4th grade students attend the class with love, find the lessons interesting and useful including lesson content and subjects, attend the lesson willingly, consider these lessons get them adopt pleasure and selection habit of listening music and accordingly they do not study lessons not only for passing the class. Additionally, it can be considered among the results obtained by this study that students who take music lesson out of school time and have another family member interested in any kind of music are statistically significantly different compared to students who do not take music lesson out of school time and have not another family member interested in any kind of music.
\end{abstract}

Keywords: Primary school, Music Lesson, Attitudes related to Music Lesson, Music Lesson Attitude Scale, Attitude

\section{Introduction}

Primary school is one of the most important stages of formal education. This period of education is composed of many important formations from learning the basic school skills such like reading, writing, calculating to characteristics modeling considering sense of conscience, system of values, acquisition of gender roles and personal freedom (Aydın, Can, Eraslanlı et. al., 2003). In primary school years, affective characteristics, such like interest, attitude and academic self-concept related to the school and lessons, start to be formed with many fundamental information, skill, concept, features and values which will affect the future periods of educational life.

In primary school program, child is taught lessons related to art education as well as basic information such like Turkish, math, science and social studies. It is known that these lessons have important contributions to hand-brain, hand-eye coordination development of child, acquisition of the creative thinking and problem solving skills, formation of self-confidence self-respect sense to him and environment, and acquisitions related to the language (Aykut, 2004). In this period, music lesson is one of those lessons given to children within the scope of art education.

Music lessons in primary school have a more distinctive and different structure than the other fields through the specific applications, creative and substantial inner dynamic. Apart from the music education, there isn't any other education program that allows students to learn by playing, trying, experiencing, singing songs and thumping out, that ensures formation of products which 
is extension of creative, critical and specific thinking, and that makes children active. Primary school students are in playing age, by nature, and music education is quite an important field in terms of allowing them to reveal their creativeness and performance which are specific to this period (Helvac1, 2012). Music lessons taught in this period is generally intended for constituting the qualified music sense and culture by ensuring development of children in cognitive, affective, psychomotor and social areas. In addition, it can be considered that music education has important contributions to obtain acquisitions regarding cohesion of the child with his/her friends in the class and out of the school and duty and responsibility comprehension to the country and society (Otacioğlu, 2004).

In addition to individual acquisitions provided by music education of primary school, it has been demonstrated by several researches that it has an influence on the success of other fields. Delehantly, in a study conducted between the years of 1981-1982 and 1982-1983, demonstrated that students taking fast learning program accompanied by music education have a positive improvement in the reading-writing, math and composition successes. In 1997, it was concluded, in the study conducted by Rausher and Shaw within the scope of effect of music education on the success of other fields, that there is statically an increase in abstract reasoning skills that are quite important for science and math lessons of students taking private piano and org lessons compared to students who take private computer lessons and have never taken music lesson. In 2006, Schellenberg carried out an experimental study on music and intelligence relation with two groups of children in Canada. In this experimental study conducted, it was seen that IQ test points of students who take music lesson are quite higher than those who don't take. It has been demonstrated by this study that music education has definitely positive influences on especially abilities to comprehend the math, intelligence and the world (trans. Şendurur \& Akgül Barış, 2002; Uluğbay, 2013; Kocabaş \& Selçioğlu, 2006). This and many such studies are important in order that positive influences of music education on the individuals can be seen clearly.

In order that music education taught to primary school children can be effective and productive, it is required to bring them in knowledge, positive attitudes and behaviors related to the music within the educational period which we call "intentional acculturation". Attitudes related to music to be acquired at these ages will not easily change after the first adulthood stage (Kocabaş, 1997). It is possible to describe the musical attitude as the musical feelings, opinions and views formed by synthesizing the experiences throughout his/her life. Music education at school should be developed in terms of musical attitude as well as cognitive development of the students (Tunalığlu, 2006). Mullins (1984) insisted on the necessity to develop attitudes of students related to the music and emphasized that if they are not developed, negative attitudes can damage a music education program quickly and deeply and accordingly attitudes have a very important role in music education (trans. Özmenteş, 2006). It can be considered that attitudes and behaviors acquired during the school years can be determinative for all learning tendencies in the educational period and can affect whole educational experience (Akman, 1992).

Many studies including musical lessons or attitudes related with music can be mentioned. In 1980, Taebel \& Coker, in the study conducted with a group of primary school students, demonstrated that variables such like socio-economic status, class level, class environment, time and music lessons taken out of the school time have an influence on attitude related to the lesson and success statistically (Taebel \& Coker, 1980). Swanwick \& Lawson in 1999, they have demonstrated that positive attitude and musical success is statistically and significantly higher in students of experiment group that had the opportunity to have a lesson with professional musicians rather than students of control group who have a lesson through traditional learning methods (Swanwick \& Lawson's, 1999). In 1985, Pogonowski carried out a study in order to determine if a difference based on musical talent, socio economic level, class level and gender variable is formed in terms of musical attitudes of students attended the Process-Oriented Music Program (POMC). Researcher carried out his study through sub-problems; 1 . To what extent musical attitudes of 
students attended the Process-Oriented Music Program (POMC) vary by socio economic level, class level and gender variables? 2. Is there any relation between low, medium or high musical talent and in-class musical attitudes? 3. Is there any relation between general attitude levels related to music lesson and attitude levels related to in-class musical experiences? 4. Is attitudes of students related to in-class music lessons associated with a) participation in school performance organizations b) whether private music lesson is taken or not? In consequence of the study, it has been reached certain findings that 1 . In-class musical attitudes of students vary by gender, socio economic level and class level, 2. Musical attitudes are not basically associated with musical talent, 3 . There is a close similarity between attitudes of student related to the music lesson and attitudes related to activities in music class, 4 . In-class musical attitudes are not affected by taking private lesson out of school time or participation in performance groups (Pogonowski, 1985).

Also for our country influences of the attitude on learning experiences and academic success have been some of the most studied subjects in recent years. When the literature is examined, you can frequently encounter studies analyzing the attitudes of students related to music lesson at various school levels and also attitude test development studies carried out in order to measure these attitudes (Kocaarslan, 2009; Babacan, Babacan \& Pirgon, 2011; Öztopalan, 2007; Saruhan, 2008, Saruhan \& Deniz, 2011; Öztürk \& Kalyoncu, 2014; Umuzdaş, 2012; Nacakc1, 2006; Koca, 2013; Varış, 2012; Otacıoğlu, 2007; Kocabaş, 1997; Saruhan, 2008; Umuzdaş \& Umuzdaş, 2015; Kocabaş \& Selçioğlu, 2006).

As understood from the researches, attitudes related to the music lesson play an important role in development of musical knowledge and skills of primary school students and positive attitudes can be developed only through a systematic approach. Measuring and evaluating the musical attitudes may give us important clues regarding whether positive attitudes have been developed or not (Öztopalan, 2007). This study conducted in the light of these views has been carried out in order to determine whether attitudes of primary school 4th grade students related to music lessons who had education during 2014-2015 academic years in the public primary schools in Çanakkale city center and whether these attitudes vary by several variables, or not. In the study, it is searched for an answer to the following questions intended for this basic purpose:

1. At which level attitudes of primary school fourth grade students related to music lesson are?

2. Do attitudes of primary school fourth grade students related to music lesson differ by taking or not taking music lesson out of school time?

3. Do attitudes of primary school fourth grade students related to music lesson differ by having or not having a family member interested in music?

\section{Method}

This study conducted in general survey model has a descriptive qualification. Such studies are conducted in order to solve the situation researched, make evaluations in direction of the specified standards and demonstrate the possible relations between events (Çepni, 2007). "General survey models are the survey arrangements, in a population formed by a large number of element, which are carried out on the whole population or a group of examples or samples taken from the population in order to make a general decision on the population" (Karasar, 2008).

\subsection{Population and Sample}

Population of the study is composed of all of the 4th grade students having education during 20142015 academic years in the public primary schools in Çanakkale city center and sample of the study is composed of 619 of 4th grade students having education in five public primary schools in Çanakkale city center. Aforementioned primary schools have been chosen by chance among the public primary schools in Çanakkale city center. These schools chosen by chance are Çanakkale Onsekiz Mart Primary School, Özlem Kayalı Primary School, Barbaros Hayrettin Primary School, Mustafa Kemal Primary School and Ticaret Borsas1 Primary School. 
Table 1. Demographic Characteristics of the Participants

\begin{tabular}{lll}
\hline $\begin{array}{l}\text { Demographic characteristics of primary school } \mathbf{4}^{\text {th }} \text { grade students } \\
\text { attended the study }\end{array}$ & $\mathbf{n}$ & $\mathbf{\%}$ \\
\hline Students who take music lesson out of the school time & 106 & 17,1 \\
Student who don't take music lesson out of the school time & 513 & 82,9 \\
Total & 619 & 100 \\
\hline Students who have a family member interested in music & 261 & 42,2 \\
Students who don't have a family member interested in music & 358 & 57,8 \\
Total & 619 & 100 \\
\hline
\end{tabular}

Table 1 illustrates the demographic characteristics of the students attended the study. Study sample is composed of 619 of primary school $4^{\text {th }}$ grade students in total. From the data in the table, it is understood that hardly $1 / 5$ of $(n=106)$ the primary school $4^{\text {th }}$ grade students attended the study take music lessons out of the school time. In addition, from the table, it can be considered that almost half of the students attended the study $(n=261)$ have a professional or amateur family member interested in music and more than half of them $(n=358)$ do not have such a family member.

\subsection{Instrument}

Data of the study has been collected by data collection tool consisting of two parts. The first part of this data collection tool includes the "personal information form" consisting of variables which may affect the attitudes of primary school 4th grade students related to music lesson and the second part includes the "music lesson attitude scale" developed by Nacakc1 (2006). Music lesson attitude scale developed by Nacakc1 (2006) is a 5 point likert scale including 15 articles. In this study, scale is rearranged as 3 point likert scale as "I agree, I am undecided and I don't agree by consulting the experts. The reason of this arrangement is that a number of confusion may arise while 4th grade students answer the scale arranged as 5 point likert, and accordingly they will be able to express their ideas in a healthy manner. In the scale, articles 1, 2, 4, 7, 12, 13 and 15 have negative and the others have positive conclusions. Scoring of the statements with negative question root has been made reversely.

\subsection{Data Analysis}

Data analysis has been made by using statistical methods which are required by the study. Parametric test hypotheses have been taken into consideration at the stage to make a decision on which techniques will be used in analysis of the sub-problems. In testing the parametric test assumptions, it has been analyzed if dependent variables are at interval or ratio scale type which is the initial condition for such tests, and the first assumption has been provided in this direction.

As for the second assumption, it is that a normal distribution is expected for the data. Kolmogorov-Smirnov test has been applied for test of normality. "Kolmogorov-Smirnov test is used in order to determine whether a sample data obtained by chance complies with a certain distribution, or not (uniform, normal or poison)" (Yazıcığglu \& Erdoğan, 2011). In consequence of Kolmogorov-Smirnov test applied for test of normality, it has been determined that average of students who take music lesson out of the school time $(D(106)=0,158, p=0,000)$ and students who don't take music lesson out of the school time $(\mathrm{D}(513)=0,0153, \mathrm{p}=0,000)$ is not suitable for the normal distribution. 
In addition, it has been determined that average of students who have a family member interested in music $(\mathrm{D}(261=0,173, \mathrm{p}=0,000)$ and students who don't have a family member interested in music $(\mathrm{D}(358=0,135, \mathrm{p}=0,000)$ is not suitable for the normal distribution.

In paired comparisons performed in direction of this results obtained, it has been decided to use Mann-Whitney U test of non-parametric tests. "Mann-Whitney U test is used in order to test if there is a significant difference between two distributions by comparing measurement of independent two groups or samples related to a dependent variable" (Ural \& K1lıç, 2011). P value is accepted as 0,05 in order to determine if there is any significant differences, and arithmetic mean and standard deviation of descriptive statistics have been used to report the results.

Answers to the questions are scored from positive to negative as "I agree (3)", "I am undecided (2)", "I don't agree (1)". As for the statements with negative question root $(5,6,8,9,10,11$ and $14)$, scoring has been made reversely.

\subsection{Reliability}

Original form of the attitude scale used in the study has been prepared with 15 articles and as 5 point likert type. As for this study, attitude scale has been prepared as 3 point likert, and reliability has been tested again by applying on the students at 4th grade. In consequence of the statistical analyses made, reliability level of the scale has been found as 0,84 (high reliability). "It is generally considered that reliability coefficient calculated for a psychological test that is 0,70 and higher is adequate in terms of the reliability of test points (Büyüköztürk, 2014). This situation can be regarded as that reliability coefficient of the scale is high and suitable for being used in the study.

\section{Findings}

Table 2. Whole Scale and Descriptive Statistics related to Scale Articles

\begin{tabular}{|c|c|c|c|c|c|c|c|c|}
\hline & \multicolumn{2}{|c|}{ Yes } & \multicolumn{2}{|c|}{ Undecided } & \multicolumn{2}{|c|}{ No } & \multirow{2}{*}{$\overline{\mathbf{X}}$} & \multirow{2}{*}{$\begin{array}{l}\text { Std. } \\
\text { Dev. }\end{array}$} \\
\hline & $\mathrm{n}$ & $\%$ & $\mathrm{n}$ & $\%$ & $\mathrm{n}$ & $\%$ & & \\
\hline $\begin{array}{l}\text { M1.I think music lesson is not an } \\
\text { important lesson. }\end{array}$ & 44 & 7,1 & 106 & 17,1 & 469 & 75,8 & 2,69 & 0,598 \\
\hline $\begin{array}{l}\text { M2.If I weren't obliged, I wouldn't } \\
\text { want to attend the music lesson }\end{array}$ & 88 & 14,2 & 95 & 15,3 & 436 & 70,4 & 2,56 & 0,729 \\
\hline $\begin{array}{l}\text { M3.I prefer to have music lesson } \\
\text { rather than math or linguistic lessons. }\end{array}$ & 190 & 30,7 & 244 & 39,4 & 185 & 29,9 & 2,01 & 0,779 \\
\hline $\begin{array}{l}\text { M4.I am not as successful as I think } \\
\text { because of my teacher. }\end{array}$ & 78 & 12,6 & 60 & 9,7 & 481 & 77,7 & 2,65 & 0,693 \\
\hline $\begin{array}{l}\text { M5.I would like to be interested in } \\
\text { music or play an instrument. }\end{array}$ & 477 & 77,1 & 84 & 13,6 & 58 & 9,4 & 2,68 & 0,638 \\
\hline $\begin{array}{l}\text { M6.I think music lessons bring me in } \\
\text { a sense of listening music and get me } \\
\text { adopt a habit of selecting. }\end{array}$ & 453 & 73,2 & 103 & 16,6 & 63 & 10,2 & 2,63 & 0,661 \\
\hline $\begin{array}{l}\text { M7.I study music lesson only to pass } \\
\text { the class. }\end{array}$ & 55 & 8,9 & 62 & 10,0 & 502 & 81,1 & 2,72 & 0,616 \\
\hline $\begin{array}{l}\text { M8.I would like to see that music } \\
\text { lessons are more in the weekly lesson } \\
\text { plan. }\end{array}$ & 288 & 46,5 & 176 & 28,4 & 155 & 25,0 & 2,21 & 0,819 \\
\hline
\end{tabular}


M9.I would like to attend the in and out of school activities through what I learned in music lesson.

M10.I find subjects of music lesson are useful and interesting for me.

M11.Music lesson is one of the lessons I love most.

M12.I prefer to allocate time for other lessons rather than music class.

M13. Music lesson is a boring one.

\begin{tabular}{llllllll}
357 & 57,7 & 156 & 25,2 & 106 & 17,1 & 2,41 & 0,765 \\
388 & 62,7 & 147 & 23,7 & 84 & 13,6 & 2,49 & 0,723 \\
346 & 55,9 & 125 & 20,2 & 148 & 23,9 & 2,32 & 0,835 \\
180 & 29,1 & 222 & 35,9 & 217 & 35,1 & 2,06 & 0,799 \\
61 & 9,9 & 102 & 16,5 & 456 & 73,7 & 2,64 & 0,655 \\
373 & 60,3 & 154 & 24,9 & 92 & 14,9 & 2,45 & 0,739 \\
& & & & & & & \\
128 & 20,7 & 98 & 15,8 & 393 & 63,5 & 2,43 & 0,812 \\
\hline
\end{tabular}
make music by an instrument or voice. technology on music lesson in terms of teaching the class.

M15.Our music teacher doesn't

When we see the findings related to the article $1,7,1 \%$ of the students agree, $17,1 \%$ of them are undecided and $75,8 \%$ of them don't agree the statement "I think music lesson is not an important lesson". General average of this statement has been at the level of X=2,69. In direction of the data obtained, it can be considered that $3 / 4$ of primary school $4^{\text {th }}$ grade students attended the study do not separate the music lesson from Math, Turkish, Science which are seen as important and think music lesson is an important lesson. In addition, it is remarkable that students who do not agree or cannot demonstrate a clear opinion related to this statement has constituted a slice of $1 / 4$. It can be considered that this situation stems from the problems based on affective characteristics of students such like interest, attitude and competence feeling related to the lesson, or from certain negative conditions related to planning and teaching the lesson.

When we see the findings related to the article $2,14,2 \%$ of the students agree, $15,3 \%$ of them are undecided and $70,4 \%$ of them don't agree the statement "If I weren't obliged, I wouldn't want to attend the music lesson". General average of this statement has been at the level of $X=2,56$. In direction of the data obtained, it can be considered that almost $3 / 4$ of primary school $4^{\text {th }}$ grade students attended the study have music class willingly. Answers given to this article is consistent the answers given to the $13^{\text {th }}$ article. It can be considered that students don't have any problem generally in music lesson and aforementioned lesson is a lesson maintained willingly.

When we see the findings related to the article 3, 30,7\% of the students agree, $39,4 \%$ of them are undecided and $29,9 \%$ of them don't agree the statement "I prefer to have music lesson rather than math or linguistic lessons". General average of this statement has been at the level of $X=2,01$. In direction of the data obtained, it can be considered that almost $3 / 4$ of primary school $4^{\text {th }}$ grade students attended the study do not prefer to have music lesson rather than math and linguistic lessons. It can be considered that this situation may result from the current examoriented system of education or a number of problems in teaching the music lessons. Little more than $1 / 3$ of the students attended the study haven't expressed any idea on this subject and so it can be considered that their ideas are not clear on this subject or they do not want to express their negative ideas.

When we see the findings related to the article $4,12,6 \%$ of the students agree, $9,7 \%$ of them are undecided and $77,7 \%$ of them don't agree the statement "I am not as successful as I think 
because of my teacher". General average of this statement has been at the level of $X=2,65$. In direction of the data obtained, it can be considered that almost $4 / 5$ of primary school $4^{\text {th }}$ grade students attended the study find themselves responsible for any failure related to music lesson. It can be considered also that class teachers generally plan and teach the music lessons as it should be.

When we see the findings related to the article $5,77,1 \%$ of the students agree, $13,6 \%$ of them are undecided and $9,4 \%$ of them don't agree the statement "I would like to be interested in music or play an instrument". General average of this statement has been at the level of $X=2,68$. In direction of the data obtained, it can be considered that excluding a part of $1 / 5$, all of the students of primary school $4^{\text {th }}$ grade student attended the study find the music as a field worth to being interested. It can be considered also that if students are guided properly, they might be willingly in a work such like playing an instrument that is important and required discipline.

When we see the findings related to the article $6,73,2 \%$ of the students agree, $16,6 \%$ of them are undecided and $10,2 \%$ of them don't agree the statement "I think music lessons bring me in a sense of listening music and get me adopt a habit of selecting". General average of this statement has been at the level of $\mathrm{X}=2,63$. In direction of the data obtained, it can be considered that with the positive answers from $3 / 4$ of the students of primary school $4^{\text {th }}$ grade students attended the study music lessons have a structure that bring a qualified music sense and that is functional in this regard. However it is remarkable that rate of students who haven't expressed any idea on the subject or have expressed negative ideas is almost $30 \%$. It can be considered that this function of music lesson is not taken into consideration in some schools.

When we see the findings related to the article $7,8,9 \%$ of the students agree, $10 \%$ of them are undecided and $81,1 \%$ of them don't agree the statement "I study music lesson only to pass the class". General average of this statement has been at the level of $X=2,72$. In direction of the data obtained, it can be considered that $4 / 5$ of primary school $4^{\text {th }}$ grade students attended the study put the music lessons in a place of education-oriented, not score-oriented, within this system of education based on exam. It can be considered also this situation indicates the interest and love of the students to music lesson.

When we see the findings related to the article $8,46,5 \%$ of the students agree, $28,4 \%$ of them are undecided and $25 \%$ of them don't agree the statement "I would like to see that music lessons are more in the weekly lesson plan". General average of this statement has been at the level of $X=2,21$. In direction of the data obtained, it is remarkable that more than half of primary school $4^{\text {th }}$ grade students attended the study haven't expressed any idea on the subject or have expressed negative ideas. It can be considered that this situation stems from the system of education based on exam and also its effects on the lessons. In addition, this findings is consistent the findings in the $3^{\text {rd }}$ article.

When we see the findings related to the article $9,57,7 \%$ of the students agree, $25,2 \%$ of them are undecided and $17,1 \%$ of them don't agree the statement "I would like to attend the in and out of school activities through what I learned in music lesson". General average of this statement has been at the level of $X=2,41$. In direction of the data obtained, it can be considered that half of primary school $4^{\text {th }}$ grade students attended the study want to present the acquisitions, which have been experienced in music lesson, at the activities in and out of the school and want to play a part willingly in such activities. This situation is consistent the findings in the article 1 and 7. As for $1 / 5$ of the students don't want to play a part in activities in and out of the school, it can be considered as it might stem from personal doubts such like timidity, feeling incompetent for attending such activities.

When we see the findings related to the article $10,62,7 \%$ of the students agree, $23,7 \%$ of them 
are undecided and $13,6 \%$ of them don't agree the statement "I find subjects of music lesson are useful and interesting for me". General average of this statement has been at the level of $\mathrm{X}=2,49$. In direction of the data obtained, as more than half of primary school $4^{\text {th }}$ grade students attended the study agree with the statement, it can be considered that they find subjects of music lesson useful personally and are such as to carry out the behavioral changes which are intended to constitute by musical education. In addition, it is remarkable that $1 / 3$ of primary school $4^{\text {th }}$ grade students attended the study haven't expressed any idea on the subject or have expressed negative ideas. It can be considered that this situation stems from the planning and teaching way of the music lessons or lack of interest of students in the lesson.

When we see the findings related to the article $11,55,9 \%$ of the students agree, $20,2 \%$ of them are undecided and $23,9 \%$ of them don't agree the statement "Music lesson is one of the lessons I love most". General average of this statement has been at the level of $X=2,32$. In direction of the data obtained, as $1 / 2$ of primary school $4^{\text {th }}$ grade students attended the study provide positive feedback to the statement in article 11, it can be considered that music lesson is a lesson which students usually love. However it is remarkable that students at the other part of $1 / 2$ haven't expressed any idea on the subject or have expressed negative ideas. It can be considered that this situation stems from perceptions, musical talents of students related to the music or problems in planning and teaching the lesson. It can be considered that findings obtained by this article and findings obtained by the article 10 are consistent.

When we see the findings related to the article $12,29,1 \%$ of the students agree, $35,9 \%$ of them are undecided and $35,1 \%$ of them don't agree the statement "I prefer to allocate time for other lessons rather than music class". General average of this statement has been at the level of $X=2,06$. Answers of primary school $4^{\text {th }}$ grade students attended the study to this statement and answers given to the article 3 are consistent. It can be considered that students have no tendency to substitute the lessons and that don't want to prefer a lesson to other one and accordingly find each lesson specific and important.

When we see the findings related to the article $13,9,9 \%$ of the students agree, $16,5 \%$ of them are undecided and $73,7 \%$ of them don't agree the statement "Music lesson is a boring one". General average of this statement has been at the level of $X=2,64$. From the data obtained, it can be considered that $3 / 4$ of primary school $4^{\text {th }}$ grade students attended the study enjoy the music lesson. Answers given to this statement and answers given to the article 2 are consistent. It can be considered that students usually attend the music lessons with love.

When we see the findings related to the article $14,60,3 \%$ of the students agree, $24,9 \%$ of them are undecided and 14,9\% of them don't agree the statement "I can see the effects of advanced technology on music lesson in terms of teaching the class". General average of this statement has been at the level of $X=2,45$. As almost $2 / 3$ of primary school $4^{\text {th }}$ grade students attended the study think that technological opportunities are represented in the music lesson, it can be considered that technological opportunities such like MIDI, computer, speaker systems, projectors, smart boards, interactive musical materials, DVD, CD, CD-ROM, electronic music devices set to work in music education of our country, as well.

When we see the findings related to the article $15,20,7 \%$ of the students agree, $15,8 \%$ of them are undecided and $63,5 \%$ of them don't agree the statement "Our music teacher doesn't make music by an instrument or voice". General average of this statement has been at the level of $X=2,43$. From the findings obtained, it can be considered that teachers working in primary school $4^{\text {th }}$ grade classes generally teach the school songs by means of their voices or a school instrument. It is remarkable that students at the other part of $1 / 3$ haven't expressed any idea on the subject or have expressed negative ideas to the statement in article 15. It can be considered this situation is due to class teachers prefer to exemplify the musical practices by benefiting the 
technologic opportunities or conduct the lesson with emphasizing on theory than practicing the lesson rather than performing the applications by means of voice or a school instrument.

Table 3. Comparison of the student averages who takes music lesson out of school time and who doesn't take music lesson out of school time

\begin{tabular}{lccccc}
\hline \multicolumn{1}{c}{ Group } & $\mathbf{n}$ & Mean rank & Total rank & U & p \\
\hline $\begin{array}{l}\text { Take music lesson out of school } \\
\text { time }\end{array}$ & 106 & 372,30 & 39464,00 & & \\
$\begin{array}{l}\text { don't take music lesson out of } \\
\text { school time }\end{array}$ & 513 & 297,13 & 152426,00 & & \\
\hline
\end{tabular}

As seen in Table 3, according to the results of Mann-Whitney U test, a statistically significant difference is observed, for the benefit of students who take music lesson out of school time, between averages of students who take music lesson out of school time and averages of students who don't take music lesson out of school time $(U=20585,00, p=0,000, Z=-3,978)$. In direction of this data, it can be considered that positive attitudes of students who take music lesson out of school time are higher.

Table 4. Comparison of the student averages who have and who don't have a family member interested in music

\begin{tabular}{lccccc}
\multicolumn{1}{c}{ Group } & n & Mean Rank & $\begin{array}{c}\text { Total } \\
\text { Rank }\end{array}$ & U & p \\
\hline $\begin{array}{l}\text { Students who have a family } \\
\text { member interested in music }\end{array}$ & 261 & 361,28 & 94294,50 & & \\
$\begin{array}{l}\text { Students who don't have a } \\
\text { family member interested in } \\
\text { music }\end{array}$ & 358 & 272,61 & 97595,50 & & \\
\hline
\end{tabular}

As seen in Table 4, according to the results of Mann-Whitney $U$ test, a statistically significant difference is observed, for the benefit of students who have a family member interested in music, between averages of students who have a family member interested in music and averages of students who don't have a family member interested in music $(U=33334,500, p=$ $0,000, Z=-6,104)$. In direction of this data, it can be considered that positive attitudes of students who students have a family member interested in music are higher.

\section{Results}

It can be said that attitudes of primary school $4^{\text {th }}$ grade students related to music lessons are positive in general. Aforementioned data has demonstrated that primary school $4^{\text {th }}$ grade students attend the music lessons with love, find the lessons interesting and useful including lesson content and subjects, attend the lessons willingly, think that these lessons bring them in sense of listening qualified music and selecting habit, and accordingly they don't study the lessons only to pass the class. These results resemble the results obtained from the researches carried out by Nacakcı (2006), Uluocak \& Tufan (2011), Koca (2013), Umazdaş \& Umuzdaş (2015).

In addition, it is seen that students find other math and linguistic lessons important as well as the music lesson and they don't have a significant tendency to choose the music lesson rather than these lessons. This is a situation that is associated with the current system of education and accordingly system of exam.

Umuzdaş \& Umuzdaş (2015), in results of the study they conducted, stated that education was turned into an exam indexed structure and that students could not allocate time to being 
interested in music among the studies to have much more scores at the exams. Uluocak \& Tufan (2011) demonstrated, in their study of the same line, the result of "No matter how much students love music lesson, they mostly prefer to allocate time for the lessons which will bring them scores. These findings and the findings obtained are consistent.

One of the results obtained by the study is that scores of students who take music lesson out of school time obtained from the attitude scale are statistically and significantly higher compared to those who don't take. Aforementioned finding can be evaluated thus; music education out of school time is completely optional and it is not affected by problems arising from the system of formal education. As it is seen this education that is called as volunteer music education has an influence on behaviors of children, it is obvious that it has positive influences on music education taught in school and affective dynamics related to music such like interest and attitude. This finding resembles the finding that "attitudes of the students who have had private music lesson for one year at least related to music lesson are more positive than attitudes of the students who have had private music lesson for one year at least related to music lesson" which was obtained from the study called "Attitudes of Secondary Students of Primary Education related to Music Lesson" carried out by Saruhan \& Deniz in 2011. In addition, the result that" being interested in music out of the school and variable of the musical experience formed accordingly have influences on musical attitudes of the students" was obtained by Yoder-White (1993) in the study carried out in order to measure influence of teachers on general music acquisitions, musical attitudes and recording performances of $6^{\text {th }}$ grade students depending on teaching effort of the teacher and the result obtained from this study are consistent (Trans: Saruhan, 2008). Similar results were obtained by the study carried out by Dirik'in 2005, and it was demonstrated that attitudes of students attending any music course related to the music lesson is higher, in positive manner, than student who don't attend.

As for final finding in the study, it is that scores of students who have a family member interested in music obtained from the attitude scale are statistically and significantly higher compared to those who don't have such a member. It is obvious that children who have a family member interested in music will have knowledge of music consciously or unconsciously. It can be considered that this situation have influences generally on development of positive attitudes related to the music and also on music lessons at school. In the post-graduate study, Öztopalan (2007) has reached a result similar to this result obtained. Researcher has stated that students of primary school are at the age in which they take their family members, teacher, etc. as model and that having a family member interested in music may affect the attitudes related to the music lesson.

This study and the other studies conducted have demonstrated that attitudes of the primary school students related to music lesson can be affected by problems due to the system of education; school, teacher and environmental factors easily. From the idea that attitudes formed at this sensitive period like primary school can affect all music lessons at other education stages, it can be recommended to increase studies within this scope and repeat them by enriching with different variables as so it will include different educational levels, as well. 


\section{Reference}

Akman, Y. (1992) The Place and Importance of Guidance in Primary Education. Hacettepe Üniversitesi Ĕ̈itimi Fakültesi Dergisi, 8, 317-320.

Aydın, B. (2003). Gelişim ve Öğrenme Psikolojisi. Binnur Yeşilyaprak (Ed.) Gelişimin Doğası (pp. 29-55) Ankara: Pegem A Yayınc1lik.

Aykut, A. (2004). Teach visual arts education in an early childhood teacher's role. Art Symposium in Early Childhood Education. Ankara: Morpa.

Babacan,E., Babacan, M. D., \& Pirgon, Y. (2011). Surveyıngon Students' Attıtudes Towards Musıc Lesson at Second Level of Prımary School. Selçuk University/Journal of Ahmet Keleşoğlu Educational Faculty,32, 325-336.

Büyüköztürk, Ş. (2014). Sosyal Bilimler İçin Veri Analizi El Kitabı. Ankara: Pegem Akademi Yayinc1lik.

Dirik, K. (2005). The effects of instrument-accompanied music courses on the students' attitudes. (Unpublished Master's Thesis). Dokuz Eylül University/Graduate School of Education Sciences, İzmir.

Helvac1, A. (2012). A Research Related To Primary School Students' Main Concepts about Music Education and Their Level of Cultural Knowledge. Uludăg University/Journal of Education, 25(2), 531-546.

Karasar, N. (2008). Bilimsel Araştırma Yöntemi. Ankara: Nobel Yayın Dağıtım.

Koca, Ş. (2013). An Investigation of High School Students' Attıtudes Towards Music Course. Çukurova University/Journal of Institute of Social Sciences. 22(2), 209-222.

Kocaarslan, B. (2009). The Comparison of Musical Attitude, Self-Esteem and Motivation Levels of Primary Grade Student's Receiving Basic Music Training. (Unpublished Master's Thesis). Marmara University/ Graduate School Of Education Sciences, İstanbul.

Kocabaş, A. (1997). A Study of Basic Education II. Valıdıty and Reliabılity of the Attıtude Scale of Towards Music. Hacettepe University/Journal of Education, 13, 141-145.

Kocabaş, A., \& Selçioğlu, E. (2006). Views of 4th and 5th Graders Students in Primary Schools about Realization Expectations and level of Music Lesson. Pamukkale University/Journal of Education, 1(19), 58-68.

Mullins, S. (1984). Attitude. The Insrumentalist, 39(5) 54-56.

Nacakc1, Z. (2006). Attitudes of Primary School Students Towards Music Lessons. National Music Education Symposium Report, 26-28 Nisan, Pamukkale University, Faculty of Education, Denizli.

Otaciğgolu, G., S. (2007). An investigation of $5^{\text {th }} 6^{\text {th }} 7^{\text {th }}$ Grade Students' Attitudes towards Music Class. Dokuz Eylül University/Journal of Buca Educational Faculty, 21, 134-139.

Özmenteş, G. (2006). Development of the Attitude Scale towards Music Class. Elementary Education Online, 5(1),23-29.

Öztopalan, E. (2007). The Relationship Between The Academic Success and the Attitude Towards the Music Lessons Among the 6th, 7th and 8th Grade Students of the State Schools and the Private Schools at Elementary Level. (Unpublished Master's Thesis). Dokuz Eylül University/ Graduate School of Education Sciences, İzmir.

Öztürk, Ö., \& Kalyoncu, N. (2014). Development of an Attitude Scale Towards Sixth Grade Music Lesson. The Journal of Academic Social Science Studies, 25(1), 235-248.

Pogonowski, L., M. (1985). Attitude Assessment of Upper Elementary Students in a ProcessOriented Music Curriculum. Journal of Research in Music Education, 33(4), 247-257.

Rauscher, F.,\& Shaw, G. (1997). Enhances Higher Brain Function. Neurological Research, Feb. 28 .

Çepni, S. (2007). Araştırma ve Proje Çalışmalarına Giriş. Trabzon: Celepler Matbaacılık.

Saruhan, Ş. (2008). The musical attitude of the 6th, 7th and 8th classes students of second level of primari education. (Unpublished Master's Thesis). Marmara University/Graduate School of Education Sciences, İstanbul.

Saruhan, Ş., \& Deniz, J. (2011). Attitudes of Secondary Level of Primary School Students Towards Music Lessons. Elementary Education Online, 10(2), 695-702. 
Swanwick, K., \& Lawson, D. (1999). 'Authentic' Music and its Effect on the Attitudes and Musical Development of Secondary School Students Institute of Education. Music Education Research, 1(1), 47-60.

Şendurur, Y., \& Akgül, Barış, D. (2002). Music Education and Cognitive Achievement of Children. Gazi University/Journal of Gazi Educational Faculty, 22(1), 165-174.

Schellenberg, G, E. (2012). Music Lessons, Emotional Intelligence, and IQ. Music Perception, 29(2), 185-194.

Taebel, D., \& K., Coker, J., G. (1980). Teaching Effectiveness in Elementary Classroom Music: Relationships Among Competency Measures, Pupil Product Measures, and Certain Attribute Variables. Journal of Research in Music Education, 28(4), 250-264.

Tunalıoğlu, S. (2006). The Influences of Regular Musical Instrument and Vocal Education Practices in Music Courses Instructed in Second Grade of Primary Schools on Students. Marmara University/Atatürk Educational Faculty Journal of Educational Sciences, 24, 179-203.

Uluğbay, S. (2013). The Effects of Music Education on Child Intelligence. Kastamonu Education Journal, 21(3), 1025-1034.

Uluocak, S., \& Tufan, E. (2011). Examination of the Attitudes of the Sixth Grade Primary School Students' Towards Music Course According to Different Variables. Kastamonu University/Journal of Kastamonu Education, 19(3), 991-1002.

Umuzdaş, M., S., \& Umuzdaş, S. (2015). Examination of The Attitudes of 8th Grade Primary School Students Regarding The Music Lesson According to Different Variables (Tokat Sample). International Journal of Turkish Education Sciences, 3(5), 273-281.

Umuzdaş, S. (2012). Development of music lesson attitude scale. International Journal of Human Sciences, (9)2, 1510-1523.

Ural, A., \& Kılıç, İ. (2011). Bilimsel Araştırma Süreci ve Spss İle Veri Analizi. Ankara: Detay Yayıncilik.

Varış, Y., A., \& Cesur, D.(2012). The Development of an Attıtude Scale Toward Secondary Education Level Music Lesson. e-Journal of New World Sciences Academy, 7(4),361-374.

Yazıcıoğlu, Y., \& Erdoğan, S. (2011). SPSS Uygulamlı Bilimsel Araştırma Yöntemleri. Ankara: Detay yayincilik.

Yoder-White, M.G., (1993). Effects of teaching intensity on sixth-grade students' general music achievements and attitudes. Unpublished Dissertation, The University of North Carolina at Greenboro, USA. 